\title{
Covid-19-pasienter med senvirkninger trenger spesialisert rehabilitering
}

Gjennom rehabilitering får pasientene ny og tilrettelagt kunnskap. De føler seg tryggere og kan håndtere hverdagen på en ny måte.

\section{Ellen Margrethe Nerheim}

\section{Sykepleier}

Avdeling for rehabilitering og livsstilsmedisin, Landsforeningen for hjerte- og lungesyke
Covid-19
Rehabilitering
Mestring
Fatigue
Endring

\section{Hovedbudskap}

Pasienter som sliter med senvirkninger etter covid-19, har behov for spesialisert rehabilitering, da de har et komplekst bilde når det gjelder langvarige symptomer. Gjennom rehabiliteringen får pasientene ny kunnskap, og de får jobbet med å endre tankegangen og vaner i en tilrettelagt hverdag. Resultatet er økt trygghet og mestring, høyere livskvalitet og håp.

SARS-CoV-2-viruset ble første gang identifisert i januar 2020 og forårsaker sykdommen covid-19 (1). I Norge har 328713 personer testet positivt for SARSCoV-2 per 15. desember 2021 (2). Andelen pasienter som opplever senvirkninger etter covid-19 uavhengig av sykdomsforløp, er i varierende grad kartlagt. 
Forskning internasjonalt rapporterer at 10-33 prosent av pasientene kan oppleve langvarig sykdom (3). En studie av ikke-sykehusinnlagte pasienter i Norge viser at 33-47 prosent opplevde symptomer 1,5-6 måneder etter covid-19 (4).

Helsedirektoratet anbefaler rehabilitering etter covid-19 når pasienten har vedvarende funksjonsproblemer, uavhengig av alvorlighetsgraden av sykdomsforløpet (5). Ved LHL-sykehuset Gardermoen har 301 pasienter per 13. desember 2021 vært til rehabilitering på grunn av senvirkninger, hvorav 52,8 prosent er menn. Gjennomsnittsalderen er 54,3 år, og 18,9 prosent er 40 år eller yngre.

I denne artikkelen beskriver jeg erfaringer vi som sykepleiere ved LHL-sykehuset Gardermoen har gjort gjennom å rehabilitere pasienter etter covid-19. Artikkelen fokuserer på hva pasientene opplever som utfordringer, og hvordan sykepleierne jobber for å møte utfordringene og bidra til å rehabilitere pasientene tilbake til en hverdag uten vedvarende funksjonsproblemer.

\section{Pasientene har vedvarende symptomer etter covid-19}

Vi har som sykepleiere erfart at pasientene som kommer til rehabilitering etter covid-19, sliter med et komplekst bilde av både fysiske, psykiske og kognitive symptomer. Tabell 1 viser de ulike symptomene som kan være vedvarende etter covid-19 (4, 6-11).

Naidu og medarbeidere finner i tillegg en sannsynlig sammenheng mellom psykisk belastning og vedvarende fysiske symptomer og en mindre sannsynlighet for å klare å komme helt tilbake i jobb (12).

Symptomene medvirker til langvarig sykefravær og samfunns $\varnothing$ konomiske konsekvenser (3). I tillegg til symptomer relatert til covid-19 har noen pasienter symptomer knyttet til komorbiditeter og/eller senskader som er knyttet til intensivbehandlingen (13). 
Tabell 1. Symptomer etter covid-19 inndelt etter funksjonsområder

\begin{tabular}{|l|l|l|l|}
\hline $\begin{array}{l}\text { Kommunikasjon/sanser/ } \\
\text { psykisk }\end{array}$ & $\begin{array}{l}\text { Åndedrett/ } \\
\text { sirkulasjon }\end{array}$ & $\begin{array}{l}\text { Ernæring/væske/ } \\
\text { eliminasjon }\end{array}$ & $\begin{array}{l}\text { Aktivitet/funksjonsstatus/ } \\
\text { smerte/søvn/hvile/velvære }\end{array}$ \\
\hline $\begin{array}{l}\text { Problemer med hukommelse } \\
\text { Problemer med } \\
\text { konsentrasjon/fokus } \\
\text { Opplevelse av «hjernetåke» }\end{array}$ & $\begin{array}{l}\text { Pusteproblemer, } \\
\text { kortpustethet, dyspné } \\
\text { Smerter / brennende følelse } \\
\text { i lungene og trachea } \\
\text { Hoste, slimproduksjon, } \\
\text { sår hals } \\
\text { Rennende nese }\end{array}$ & Tap av matlyst & Muskelsvakhet \\
\hline $\begin{array}{l}\text { Tinnitus } \\
\varnothing \text { reverk } \\
\varnothing y e p r o b l e m e r\end{array}$ & $\begin{array}{l}\text { Brystsmerter } \\
\text { Opplevelse av stramninger } \\
\text { i brystet } \\
\text { Ubehag i brystet } \\
\text { Svimmelhet }\end{array}$ & $\begin{array}{l}\text { Endringer i luktesans } \\
\text { Endringer i smak }\end{array}$ & $\begin{array}{l}\text { Leddsmerter } \\
\text { Huskelsmerter } \\
\text { Hodepine }\end{array}$ \\
\hline $\begin{array}{l}\text { Depresjon } \\
\text { Angst } \\
\text { PTSD }\end{array}$ & $\begin{array}{l}\text { Hjertebank } \\
\varnothing \text { kt hvilepuls }\end{array}$ & $\begin{array}{l}\text { Kvalme } \\
\text { Magesmerter }\end{array}$ & Søvnvansker (Insomnia) \\
\hline Nedsatt livskvalitet & $\begin{array}{l}\text { Forhøyet kroppstemperatur } \\
\text { Svetting, hetetokter }\end{array}$ & Diaré & $\begin{array}{l}\text { Ekstrem tretthet } \\
\text { (utmattelse/fatigue) }\end{array}$ \\
\hline
\end{tabular}

Kilder: $(4,6-11)$

\section{Pasientene hadde utfordringer i hverdagen før rehabiliteringen}

Pasientene som kommer til rehabilitering ved LHL-sykehuset, forteller at de har opplevd begrensninger på mange områder samtidig. De uttrykker at de kjenner på stress, tankekjør og bekymringer, uvisshet og usikkerhet. De opplever at symptomene gjør hverdagen uforutsigbar og vanskelig å planlegge.

Pasientene forteller om et stort fall i det å gå fra full jobb til at kroppen ikke fungerer, og de ikke klarer å jobbe. I tillegg forteller de at det er vanskelig for andre å forstå hvordan de har det, og at de kan bli mistrodd, da de ser friske ut. De kan oppleve press blant annet fra arbeidsgiveren siden det er vanskelig å forutsi lengden på sykmeldingen.

I og med at covid-19 er en ny sykdom, uttrykker pasientene at de ikke vet hva de kan forvente av bedring, eller hvor lang tid det kommer til å ta.

\section{Rehabilitering krever helhetlig tankegang og tverrfaglighet}

Helsedirektoratet skriver i sin veileder om SARS-CoV-2 at rehabilitering anbefales tidlig for intensivinnlagte, og at det bør vurderes etter mildt eller moderat sykdomsforløp der symptomer vanskeliggjør jobbing og deltakelse i hverdagsaktiviteter fire uker etter sykdomsdebuten (5). Et helhetlig perspektiv er viktig i rehabiliteringen med tanke på kompleksiteten av de fysiske, psykiske og kognitive utfordringene $\left(5,13^{-14}\right)$. 
På LHL-sykehuset Gardermoen har pasientene god nytte av et tett tverrfaglig samarbeid med lang erfaring og kompetanse innen spesialisert

rehabilitering. Mange av problemstillingene i det komplekse bildet etter covid-19 er kjent for det tverrfaglige teamet gjennom vår bakgrunn fra å rehabilitere hjerte- og lungepasienter.

Det tverrfaglige teamet består av sykepleier og hjelpepleier, lege, fysioterapeut, ergoterapeut, ernæringsfysiolog, sosionom og psykolog, og rehabiliteringen inkluderer også mulighet for utredning (15).

\section{Sykepleieren har ulike oppgaver i oppfølgingen}

Ved innkomst gjennomfører sykepleieren en helhetlig kartleggingssamtale med pasientene. Sykepleieren tar utgangspunkt i de ulike funksjonsområdene, og samtalen inkluderer hvilke symptomer pasientene kjenner på, og hvilke utfordringer de sliter med.

Pasientene setter selv mål for oppholdet og den påfølgende tiden hjemme ut ifra hva som er viktig for dem, slik Helsedirektoratets veileder for rehabilitering anbefaler (16). Sykepleieren oppretter en tverrfaglig rehabiliteringsplan med utgangspunkt i målene.

\section{«Vi som sykepleiere har erfart at progresjonen er rask, og at pasientene blir selvhjulpne i løpet av de fire ukene de er på rehabilitering.»}

Sykepleieren har også ansvar for å gjennomføre seks minutters gangtest. Testen gir mål på opplevd tungpust, maksimal ganglengde samt utvikling i oksygenmetning og puls over seks minutters gange på flatt underlag, hvilket reflekterer funksjonell kapasitet i dagliglivets aktiviteter (17).

Noen pasienter kommer direkte til rehabiliteringen fra sykehus etter langvarig sengeleie. De dårligste pasientene har i begynnelsen behov for praktisk tilrettelegging $\mathrm{i}$ forbindelse med blant annet personlig hygiene og måltider. Noen trenger ganghjelpemidler initialt.

Vi som sykepleiere har imidlertid erfart at progresjonen er rask, og at pasientene blir selvhjulpne i løpet av de fire ukene de er på rehabilitering. Pasienter forteller oss om følelsen av å ikke få pustet godt nok, og/eller de opplever tungpust selv ved lette anstrengelser. Forskning viser at pasienter som har hatt et alvorlig forløp av covid-19, kan ha nedsatt gassdiffusjon og endringer på lungene $(9,11)$. 


\section{Pasientene har behov for veiledning}

Sykepleieren gir opplæring i oksygenutstyr og -bruk hvis pasienten har behov for oksygentilskudd. Ved underliggende lungesykdom underviser sykepleieren i bruk av inhalasjonsmedisiner og mestring av forverringer. Ved mistanke om uhensiktsmessig pustem $\varnothing n s t e r$ kartlegger sykepleieren eller fysioterapeuten hyperventilering ved hjelp av Nijmegen Questionnaire (18).

Pasienter kan ved hyperventilering oppleve tungpust, svimmelhet og stramninger i brystet. I tillegg er det en kjent assosiasjon mellom hyperventilering og psykisk stress og angst (19). Både de nevnte fysiske symptomene og psykisk påvirkning er kjent etter covid-19 (se tabell 1).

Ved en skår på 20 eller høyere på Nijmegen Questionnaire (20) gjennomgår sykepleieren informasjon relatert til hyperventilering med pasienten inkludert veiledning i pusteteknikk og teknikker for avspenning.

Dagene på rehabiliteringen starter med at sykepleiere og pasienter samles på morgenmøte med status for dagen og mulighet for å ta opp spørsmål. Sykepleieren observerer pasientens utfordringer innen de ulike funksjonsområdene gjennom dagen og iverksetter tiltak.

Vi som sykepleiere opplever i tillegg at pasientene i stor grad har behov for støttesamtaler og veiledning, og sykepleieren har regelmessige samtaler med pasienten. Pasienten tilbys også mulighet til å inkludere pårørende i en samtale i løpet av oppholdet.

I tillegg til individuelle avtaler inneholder rehabiliteringen undervisninger, treningsøkter og samtalegrupper. Organisatorisk er pasientene delt i team på 15 pasienter med eget personell i de ulike faggruppene tilknyttet det enkelte teamet.

\section{Pasientene har ulike samtalegrupper og støttesamtaler}

Vår erfaring er at samtaler utgjør en viktig del av rehabiliteringen. For mange av pasientene er samtalene avgjørende for at de klarer å komme seg videre i livet og tilbake til hverdagen.

Samtalene mellom sykepleieren og pasienten handler om å bearbeide, å få verktøy for bedre å kunne mestre en annerledes hverdag og å formidle håp. Pasientene øver på å sortere bekymringer og uro og å lære seg å leve med en endret hverdag med foreløpige begrensninger. 


\section{«Pasientene får $\emptyset v e$ seg på å sortere bekymringer og uro og å lære seg å leve med en endret hverdag med foreløpige begrensninger.»}

De gir uttrykk for at de vil mye mer enn hva kroppen klarer å gjennomføre, og i mange tilfeller opplever vi at samtalene handler om en mental justering med tanke på hva kroppen aksepterer.

De samme temaene går igjen i samtalegruppene og i de individuelle samtalene mellom sykepleieren og pasienten. Samtalegruppene blir ledet av to sykepleiere. Det er totalt fire grupper à 45-60 minutter med et fastsatt tema.

I tillegg har andre faggrupper samtalegrupper med andre temaer. Primærsykepleieren avtaler støttesamtaler med pasienten etter behov. Jeg gjennomgår innholdet i samtalegruppene i det følgende.

\section{Pasientene utveksler erfaringer med covid-19}

Våre pasienter forteller at utveksling av erfaringer med å ha hatt covid-19 har stor verdi for dem. Selv om forløpene har vært ulike, både med og uten sykehusinnleggelser, ser vi at pasientene har behov for å dele erfaringene med andre som har kjent sykdommen på kroppen.

De har kjent på skammen over å ha fått covid-19, ensomheten i å bli rammet av sykdommen og redselen for å bli alvorlig syk. Noen av pasientene sliter med minnene etter intensiv- og respiratorbehandling.

For andre skaper følelsen av utmattelse, nedsatt hukommelse og de ulike fysiske symptomene mye usikkerhet, fortvilelse og engstelse. Vi som sykepleiere opplever stadig at pasientene trekker et lettelsens sukk over å få vite at utfordringene ikke bare gjelder dem.

Covid-19 er fortsatt såpass nytt at pasientene ikke vet hva de kan forvente etter å ha gjennomgått sykdommen. De sier at formen kan svinge fra dag til dag. De kan dele erfaringer rundt opplevelsen av å ikke strekke til og ikke klare å leve opp til verken sine egne eller andres krav og forventninger.

Pasientene forteller om manglende forståelse for begrensningene de opplever, og at de kjenner seg ensomme i kampen om å få hverdagen til å fungere. De kjenner også på usikkerhet for hvordan livet blir videre, og hvordan livskvaliteten vil bli når de ikke vet hva fremtiden bringer. 


\section{Sykepleieren og pasienten ser på mestringsstrategier}

Vi erfarer at bevisstgjøring rundt energiregnskap er essensielt for mange av dem som sliter med senvirkninger etter covid-19. Pasientene gir uttrykk for at de forventer at de skal klare det samme som før, men at det fører til gjentatte opplevelser av nederlag. I denne samtalegruppen legger sykepleierne vekt på at det er viktig med prioriteringer, og vi ser sammen med pasientene på mulige mestringsstrategier i jobben med å komme videre i livet.

Vi fokuserer på balansen mellom aktivitet og hvile og at hverdagen er slik at det skapes et overskudd i kroppen fremfor gjentatte nederlag. Vi $\varnothing$ nsker å gi en $\varnothing \mathrm{kt}$ forståelse for energiregnskap som giør at pasientene opplever at de tar kontroll over sitt eget liv, og dermed opplever $\varnothing \mathrm{kt}$ trygghet.

\section{«Sykepleieren hjelper pasientene til å bli bevisst på hva som gir og tapper energi hos den enkelte.»}

I samtalegruppen benytter vi flere av elementene som oppslagsverket UpToDate anbefaler under behandling av vedvarende symptomer etter covid-19 (10). Sykepleieren hjelper pasientene til å bli bevisst på hva som gir og tapper energi hos den enkelte. Sykepleieren ber pasientene tenke igjennom hva som bedrer og forverrer situasjonen (figur 1 og 2 ).

Når på døgnet opplever pasientene at de fungerer best, og hva er viktigst for dem å prioritere i hverdagen når noe må prioriteres bort eller omprioriteres? Vi erfarer at det å gjøre positive ting kan bli negativt for pasientene hvis det ikke er nok hvile mellom aktivitetene. Hva er ting de må gjøre, hva bør de gjøre, og hva har de lyst til å gjøre? 


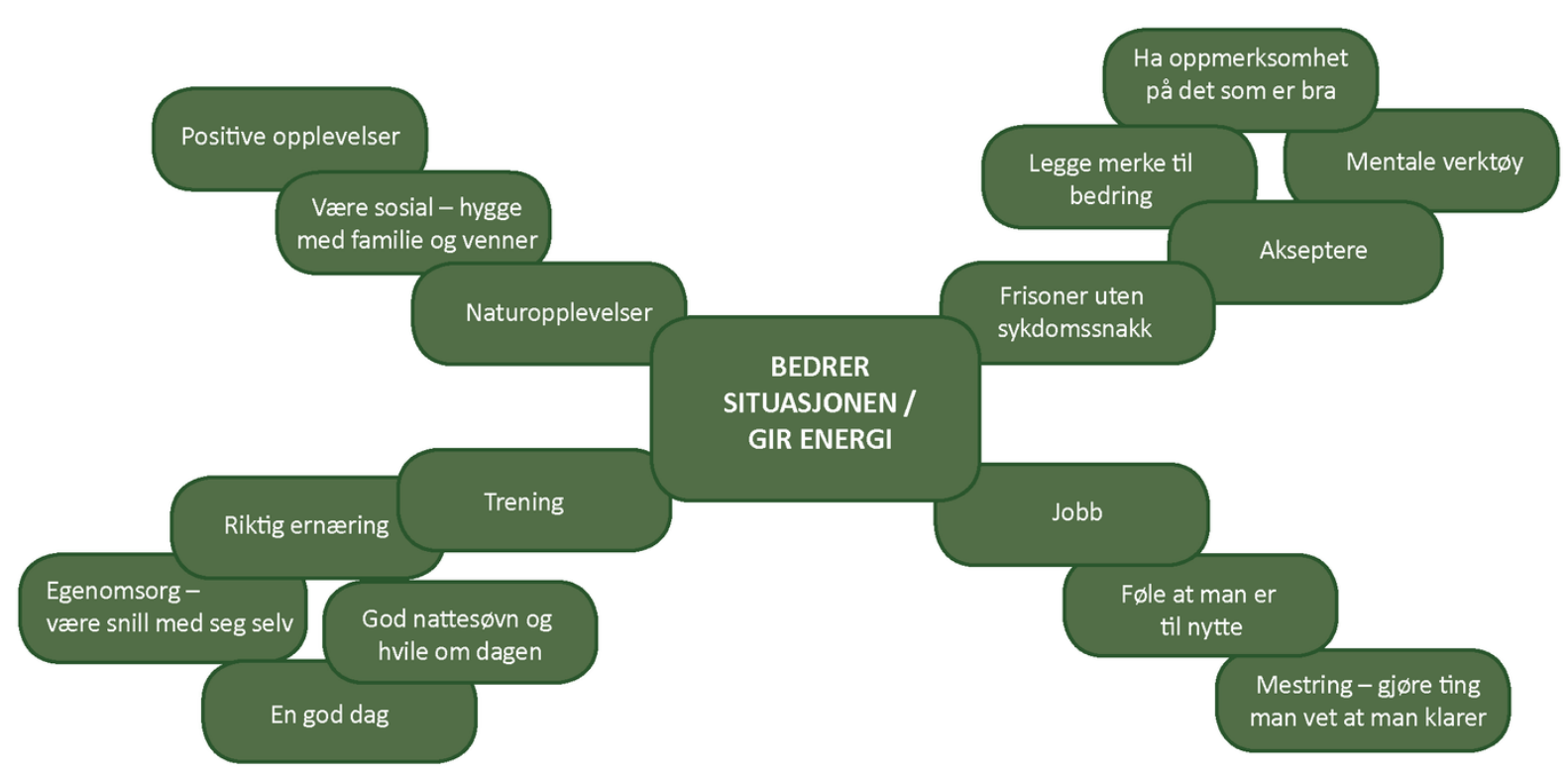

Figur 2. Pasientopplevelser: Hva forverrer situasjonen og tapper energi?

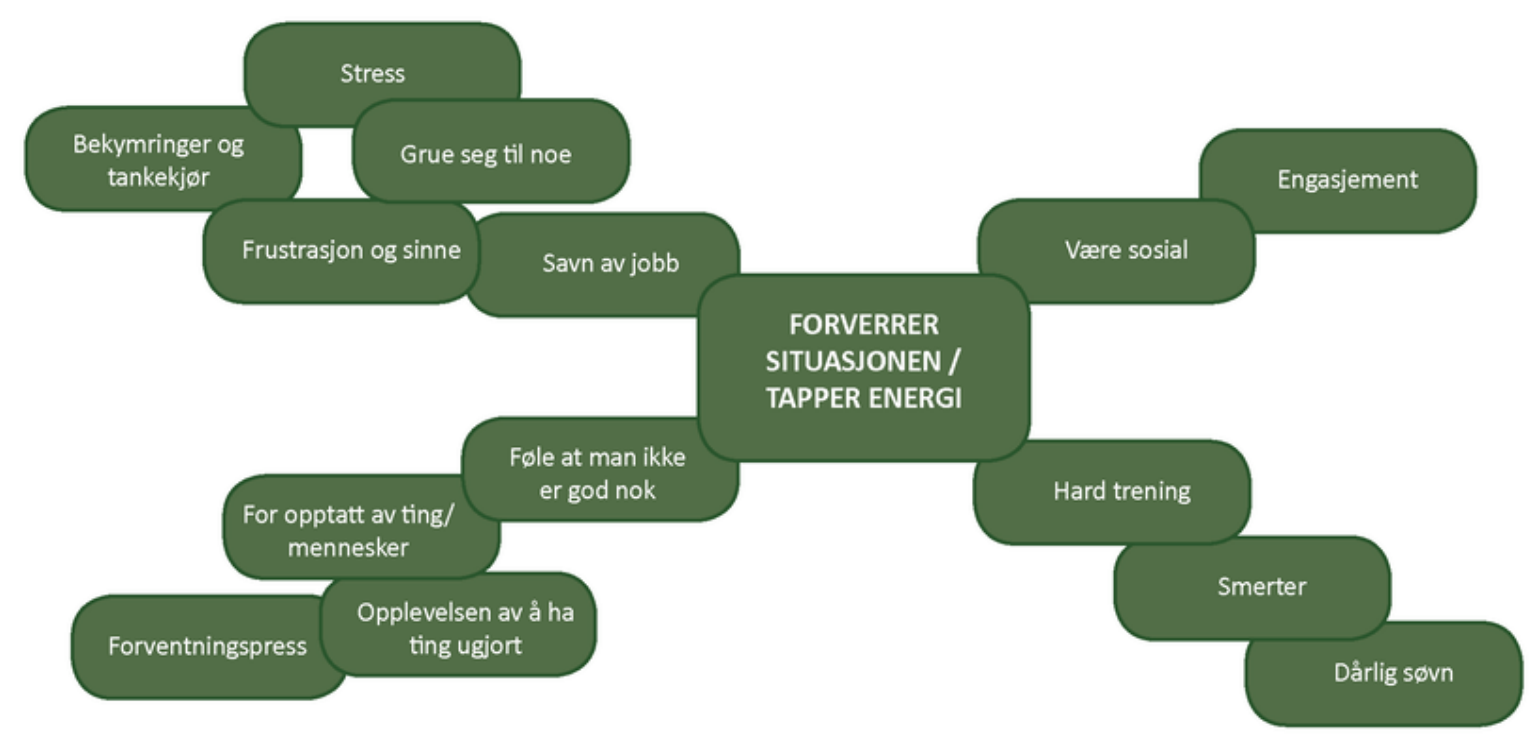

Sykepleieren snakker om viktigheten av å ha en plan, finne balansen, tenke grensesetting og å tette energilekkasjene i hverdagen. I samtalegruppen bruker vi blant annet Skje-teorien (se faktaboks nedenfor) til å forklare energiregnskapet (21).

Vi opplever at mestringen ligger i bevisstheten om og forståelsen av hva pasientene trenger å endre i sin egen hverdag for at den skal fungere bedre. Energiregnskapet blir et verktøy for bedre stressmestring og håndtering av livet, som brått ble endret på grunn av sykdommen. 


\section{«The Spoon Theory»}

Hvis du antar at du starter dagen din med ti skjeer, hvor hver skje representerer energien du bruker på ett daglig gjøremål, hvordan ville dagen din sett ut?

- 1 SKJE: Stå opp og gå ut av senga.

- 1 SKJE: Dusje og stelle seg.

- 1 SKJE: Kle på seg.

- 1 SKJE: Lage frokost.

- 1 SKJE: Gå til bussen eller til bilen.

Nå har du brukt opp halvparten av skjeene dine, og dagen har så vidt begynt. Hva gjør du nå? Hvordan skal du fordele resten av skjeene slik at du kommer deg igjennom dagen uten å bli utmattet? Du kan «låne» skjeer fra dagen etter, men da kan du måtte betale for det i dagene etterpå. A ha en slik konkret metafor for hvordan det føles å være utmattet, kan hjelpe både de rundt deg og deg selv med å forstå hvordan sykdommen påvirker livet ditt.

\section{Kilde: Norsk Revmatikerforbund}

\section{Pasientene kan kjenne på lavere egenverdi}

Samtalegruppen om verdi og selvfølelse tar utgangspunkt $i$ at endringer og erfaringer påvirker oss som mennesker, og hvordan vi oppfatter oss selv og føler oss (22).

Pasientene på rehabiliteringen har opplevd ulike endringer etter covid-19, slik som endret helse og fravær fra jobb og sosial deltakelse, hvilket igjen har påvirket hvordan de ser på seg selv. De forteller at de opplever at de ikke kjenner seg selv igjen, og de kan kjenne på lavere egenverdi når de ikke klarer det samme som før.

Selvfølelse handler om opplevelsen av å være verdt noe i egne øyne uavhengig av prestasjoner, altså en aksepterende innstilling til seg selv (22). En god selvfølelse bidrar til økt tro på egen mestring, mens ulike reaksjoner som sinne, nedstemthet, negative tanker og bekymring for fremtiden kan bidra til opplevelsen av å ikke mestre.

Sykepleieren utfordrer pasientene til å tenke igjennom hva som får frem det beste i dem, hva som motiverer dem mest, og hvordan de kan påvirke sin egen selvfølelse. Pasientene kan først diskutere temaene to og to og deretter i plenum i samtalegruppen, slik at det blir best mulig refleksjon og samtale om temaet. Vi avslutter gjerne gruppen med en avspenningsøvelse. 


\section{Hvordan blir veien videre?}

I denne samtalegruppen reflekterer sykepleieren og pasientene sammen rundt hvilken hverdag pasientene ønsker å komme tilbake til, og hvordan de kan fortsette prosessen de har kommet i gang med på rehabiliteringen.

Pasientene trenger i varierende grad å håndtere utmattelse og fysiske symptomer når de kommer hjem. De ønsker å komme tilbake til en hverdag som fungerer, men tidsaspektet og veien for å komme dit kan fortatt være usikker. Sykepleieren oppfordrer pasientene til å sette ord på forventninger til seg selv og fra andre. Hvordan ønsker de å forholde seg til familie, venner og jobb?

\section{«Pasientene jobber med å justere tankegangen og sine egne forventninger til det kroppen faktisk klarer.»}

Vi ser gjentatte ganger at pasienter har som mål å jobbe 100 prosent rett etter rehabiliteringsoppholdet, men at de selv justerer målet underveis, setter seg delmål og har et lengre perspektiv på rehabiliteringen enn bare rehabiliteringsoppholdet.

Pasientene jobber med å justere tankegangen og sine egne forventninger til det kroppen faktisk klarer. Vi snakker om at senvirkninger etter covid-19 kan ta tid, og at det er viktig å erkjenne at det er vanskelig nå, men samtidig er det håp. Tidsperspektiv, tilpasninger og trygging er viktige stikkord (14). Vi hjelper pasientene til å se det større bildet, ikke bare fra dag til dag.

\section{Rehabiliteringen er viktig for pasientene}

Vi har erfart at pasientene synes det har vært godt å bli møtt av et helhetlig tenkende, tverrfaglig team som har gjort individuelle tilpasninger, og har erfaring fra kompleks rehabilitering. Ulike former for tester og hjelp til å legge vekk stress, tankekjør og bekymringer har vært viktig for pasientene.

Rehabiliteringsoppholdet har gjort at pasientene har kunnet konsentrere seg om å komme tilbake til hverdagslivet uten alle de andre rollene de har hjemme.

Pasientene opplever at fastlåste mønstre er mulig å endre.

De opplever at uforutsigbarhet, uvisshet og usikkerhet gradvis er erstattet av en realistisk forventning, trygghet og verktøy til å håndtere hverdagen videre med tanke på at noe av uforutsigbarheten fortsatt kan være der. 
Selv om pasientene ikke nødvendigvis vet hvor lang tid det tar å komme tilbake til hverdagen slik den var før covid-19, uttrykker de at de vet mer om hva de kan gjøre, og hvordan de kan håndtere livet for å jobbe i retning av den hverdagen de ønsker å ha. De forteller at det også har vært viktig for dem å dele erfaringer, møte andre i samme situasjon og samtale med andre som forstår dem.

\section{Oppsummering}

Vi som sykepleiere ser at pasientene har behov for spesialisert rehabilitering etter covid-19, da de har et komplekst bilde når det gjelder senvirkninger. Gjennom rehabiliteringen erfarer vi at pasientene får ny kunnskap, og de får jobbet med å endre tankegangen og vaner i en tilrettelagt hverdag.

Vi ser at pasientene opplever $\varnothing \mathrm{kt}$ trygghet og har fått en basis for å håndtere hverdagen på en ny måte. Rehabilitering tar imidlertid tid, og endringene som pasientene har startet under oppholdet, må de vedlikeholde etter utreise.

Erfaringen er at pasientene ved utreise er godt motivert for å fortsette endringene som er påbegynt, og de gir uttrykk for økt livskvalitet og håp om en bedre hverdag.

En stor takk til Berit Skollerud og Liv Hasund Eid for viktige bidrag fra klinisk arbeid med pasientgruppen og gjennomlesning av artikkelen.

\section{Referanser}

1. Folkehelseinstituttet (FHI). Fakta om koronaviruset SARS-CoV-2 og sykdommen covid-19. Oslo: FHI; 2021. Tilgjengelig fra: https://www.fhi.no/nettpub/coronavirus/fakta-og-kunnskap-om-covid-19/fakta-omkoronavirus-coronavirus-2019-ncov/?term=\&h=1 (nedlastet 11.08.2021).

2. Folkehelseinstituttet (FHI). Statistikk om koronavirus og covid-19. Oslo: FHI; 2021. Tilgjengelig fra: https://www.fhi.no/sv/smittsomme-sykdommer/corona/dags-og-ukerapporter/dags--og-ukerapporter-om-koronavirus/ (nedlastet 15.12.2021).

3. Lindholm E, Tønnesen TI. Langvarig syk etter covid-19. Tidsskrift for Den norske legeforening. 2020;(14). DOI: 10.4045/tidsskr.20.0753

4. Stavem K, Ghanima W, Olsen MK, Gilboe HM, Einvik G. Persistent symptoms 1.5-6 months after COVID-19 in non-hospitalised subjects: a population-based cohort study. Thorax. 2021;76(4):405-7.

5. Helsedirektoratet. Koronavirus - beslutninger og anbefalinger. Kapittel 11. Rehabilitering etter covid-19. Oslo: Helsedirektoratet; 2021. Tilgjengelig fra: https://www.helsedirektoratet.no/veiledere/koronavirus (nedlastet 09.05.2021). 
6. National Health Services UK. Long-term effects of coronavirus (long COVID). National Health Services UK; 2021. Tilgjengelig fra:

https://www.nhs.uk/conditions/coronavirus-covid-19/long-term-effects-ofcoronavirus-long-covid/ (nedlastet 15.04.2021).

7. Goërtz YMJ, Van Herck M, Delbressine JM, Vaes AW, Meys R, Machado FVC, et al. Persistent symptoms 3 months after a SARS-CoV-2 infection: the postCOVID-19 syndrome? ERJ Open Res. 2020;6(4):00542.

8. Carfi A, Bernabei R, Landi F. Group ftGAC-P-ACS. Persistent symptoms in patients after acute COVID-19. JAMA. 2020;324(6):603-5.

9. Lerum TV, Aaløkken TM, Brønstad E, Aarli B, Ikdahl E, Lund KMA, et al. Dyspnoea, lung function and CT findings three months after hospital admission for COVID-19. Eur Respir J. 2021;57(4):2003448.

10. UpToDate. Patient education: recovery after COVID-19 (basics). UpToDate; 2021. Tilgjengelig fra: https://www.uptodate.com/contents/recovery-after-covid-19the-basics?search=rehabilitation\%2opostcovid\&amp;source=search_result\&amp;selectedTitle=17 150 (nedlastet 26.04.2021).

11. Huang C, Huang L, Wang Y, Li X, Ren L, Gu X, et al. 6-month consequences of COVID-19 in patients discharged from hospital: a cohort study. Lancet. 2021;397(10270):220-32.

12. Naidu SB, Shah AJ, Saigal A, Smith C, Brill SE, Goldring J, et al. The high mental health burden of «Long COVID» and its association with on-going physical and respiratory symptoms in all adults discharged from hospital. Eur Respir J. 2021;57(6):2004364.

13. Barker-Davies RM, O'Sullivan O, Senaratne KPP, Baker P, Cranley M, DharmDatta S, et al. The Stanford Hall consensus statement for post-COVID-19 rehabilitation. Br J Sports Med. 2020;54(16):949-59.

14. Helsedirektoratet. Webinar 8: rehabilitering etter covid-19. Oslo: Helsedirektoratet; 2021. Tilgjengelig fra: https://www.helsedirektoratet.no/veiledere/koronavirus/personell-kompetanse-ogrekruttering/kurs-og-opplaering/rehabilitering-kurs-og-webinarer/webinarer-omrehabilitering-etter-covid-19 (nedlastet 11.08.2021) 
15. LHL-sykehuset Gardermoen. Rehabilitering - for hjerte- og lungepasienter. Jessheim: LHL-sykehuset Gardermoen; 2021. Tilgjengelig fra: https://www.lhl.no/gardermoen/rehabilitering/ (nedlastet 28.05.2021).

16. Helsedirektoratet. Rehabilitering, habilitering, individuell plan og koordinator. Oslo: Helsedirektoratet; 2020. Tilgjengelig fra:

https://www.helsedirektoratet.no/veiledere/rehabilitering-habilitering-individuellplan-og-koordinator/formal-og-overordnede-prinsipper-for-habilitering-ogrehabilitering-individuell-plan-og-koordinator/gjennomgang-av-definisjonen-avhabilitering-og-rehabilitering (nedlastet 31.05.2021).

17. American Thoracic Society. ATS statement: guidelines for the six-minute walk test. Am J Respir Crit Care Med. 2002;166(1):111-7.

18. van Dixhoorn J, Duivenvoorden HJ. Efficacy of Nijmegen Questionnaire in recognition of the hyperventilation syndrome. J Psychosom Res. 1985;29(2):199206.

19. Schwartzstein RM, Richards J, Edlow JA, Roy-Byrne PP. Hyperventilation syndrome in adults. UpToDate; 2021. Tilgjengelig fra: https://www.uptodate.com/contents/hyperventilation-syndrome-in-adults? search=hyperventilation\&amp;source=search_result\&amp;selectedTitle=1 150 (nedlastet 10.06.2021).

20. Azizmohammad LM, Masaebi F, Abedi M, Mohseni N, Fakharian A. The optimal cut-off score of the Nijmegen Questionnaire for diagnosing hyperventilation syndrome using a bayesian model in the absence of a gold standard. Galen Med J. 2020;9:e1738.

21. Norsk Revmatikerforbund. Når de rundt deg ikke forstår. Oslo: Norsk Revmatikerforbund; 2019. Tilgjengelig fra: https://www.revmatiker.no/nar-de-rundtdeg-ikke-forstar/ (nedlastet 26.08.2021).

22. Onlinepsykologene. Selvfølelse. Onlinepsykologene; 2021. Tilgjengelig fra: https://onlinepsykologene.no/vanlige-psykiske-plager/selvfolelse/ (nedlastet 26.08.2021). 